\title{
Hamsa
}

Journal of Judaic and Islamic Studies

$5 \mid 2019$

Muslims and Jews in Latin America

\section{The Global "War on Terror" and the Tenuous Public Space of Muslims in Latin America and the Caribbean}

Ken Chitwood

(2) OpenEdition

Journals

Electronic version

URL: https://journals.openedition.org/hamsa/443

DOI: 10.4000/hamsa.443

ISSN: 2183-2633

Publisher

CIDEHUS - Centro Interdisciplinar de História Culturas e Sociedades da Universidade de Évora

Electronic reference

Ken Chitwood, "The Global "War on Terror" and the Tenuous Public Space of Muslims in Latin America and the Caribbean", Hamsa [Online], 5 | 2019, Online since 31 March 2019, connection on 16

September 2021. URL: http://journals.openedition.org/hamsa/443 ; DOI: https://doi.org/10.4000/ hamsa.443

This text was automatically generated on 16 September 2021.

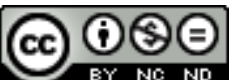

Hamsa est mise à disposition selon les termes de la Licence Creative Commons Attribution - Pas d'Utilisation Commerciale - Pas de Modification 4.0 International. 


\title{
The Global "War on Terror" and the Tenuous Public Space of Muslims in Latin America and the Caribbean
}

\author{
Ken Chitwood
}

On 31 October, 2017 the FBI surmises that Uzbeki national Sayfullo Habibullaevic Saipov drove a rented truck into cyclists and runners along the Hudson River Park bike path in Lower Manhattan, New York. Al-Dawla al-Islamiyya took responsibility for the attack in its newsletter, al-Naba, and claimed Saipov as one of their own - a "soldier of the Caliphate" who responded to its call to attack "citizens of the Crusader countries." Eight people were killed. Eleven more were severely injured. Those killed included five Argentines.

2 This attack was framed by news outlets as a salvo in the global "War on Terror" and cast against the backdrop of previous "terror attacks" in the region. Responding to the attack and the loss of Argentine lives, President Mauricio Macri said the attack hit all Argentines hard and that "there is no place for gray areas" in the fight against terrorism. ${ }^{1}$ Macri won the Argentine presidency in 2015 and ran on a platform that included a firm stance against "radical terror." This stance was not only part of the broader U.S.-led global "War on Terror," but drew on specific specters from Argentinia's own past - specifically the 1994 bombing of the Argentine-Israeli Mutual Association (AMIA), in which eighty-five people were killed. Indeed, some news outlets highlighted how the truck attack was the "deadliest attack in NYC since 9/11"2 or inflected how Argentina, "Home to Deadliest Jihad in Hemisphere Before 9/11, [was] Struck Again in NYC." ${ }^{3}$ Along with flowers and candles at the makeshift memorial setup at Chambers and West Streets, there also hung an Argentine flag and football jersey. "STOP TERRORISM" was scrawled on one of the temporary barriers put in place as a means to improve the bike path's safety.

3 Keeping these attacks and reactions in mind, this essay explores the many linkages between the Americas and the concept of the global "War on Terror." Focusing on cases in Latin America and the Caribbean, but also drawing on broader currents in the 
Americas as a whole, this essay examines how Muslims occupy a tenuous space in the Latin American and Caribbean public spheres amidst the global "War on Terror" and its attendant fears, politics, and state actions. It will include an overview of how both global and local narratives inform how Muslims are viewed in each country and how two separate attacks - each with their own origins and implications - are now caught up in a much larger narrative as part of the global "War on Terror."

\section{The Global “War on Terror," U.S. Politics, Media, and the Americas}

4 While the U.S. has been involved in "fighting terrorism"4 over the last thirty to forty years in places as diverse as Kenya, Iran, Afghanistan, and Colombia, it was not until after 9/11 that the "War on Terror" - or global "War on Terror" amorphous shape. Since its inception, and by definition, the global "War on Terror" is international in scope and untraditional in the ways that it constitutes war. This means that it has expanded the U.S. government's imperial reach and justified myriad actions that would have been considered out of bounds in previous engagements (for example the killing of U.S. citizen Anwar Al-Alawki in Yemen via a drone strike) and in places where the U.S. is not formally "at war." Although the geography of this war is focused on the Middle East, North Africa, and South and Central Asia, it has also included in its landscape countries in Africa, Southeast Asia, Europe, and Latin America. ${ }^{6}$

The rationale for this global conflict is that since terrorism is a worldwide problem both in origin and outcome - so too must be the response. Michael Chandler and Rohan Gunaratna wrote, " $[t]$ he roots of extremism that translate into the threat posed today by transnational terrorism run much deeper and have to be confronted globally, at every level of the problem."7 Imagining the threat as mobile and transnational - what has been called "network terrorism" - the U.S. government has justified its far-reaching actions by citing how terrorists are no longer limited to nation-states like Afghanistan or Iraq, but that they threaten and violate the sovereignty of each and every nation. For evidence of this networked and intercontinental terrorist threat they cite attacks in France, California, and Nigeria. They also look to examples from Latin America and the Caribbean, such as those we will discuss in the remainder of this article.

The rationale for this war also draws on the "clash of civilizations" thesis of Samuel P. Huntington, among others. ${ }^{9}$ Huntington proposed his thesis in response to his pupil Francis Fukuyama's 1992 book, The End of History and the Last Man ${ }^{10}$ and made the case that peoples' religious and cultural identities will be the primary source of conflict in the world following the end of the Cold War. Huntington argued that wars would not be fought between countries per se, but between cultures. Among these, Islamic cultures and their extreme expressions would pose the most serious threat to world peace. This theory has led to a range of policies, actions, and political perspectives which openly target Muslims and those associated with them. In this drama, "Muslims have been cast as subaltern citizens in the West" both ideologically and systematically through "xenophobic state policies, new citizenship regimes, and racial and religious profiling" in the post-9/11 world and in the "global context of the U.S.-led "War on Terror." 11 Indeed, as can be gleaned from the concrete details and commentary before, "[t]he hegemonic discourses framing [the War on Terror] have been about the security of the 
American nation and consequently of all Western nations [including the American hemisphere as a whole]. This discourse of bringing security and peace to the world was deployed as a moral prop by many Western states for legitimating massive killings of people of colour overseas and the draconian policies targeting Muslims of colour within the nations of the West." ${ }^{12}$

This war is said to have fronts in Latin America and the Caribbean as well. To be fair, there have been attacks in the region including the aforementioned incident in Argentina in the 1990s among others. Furthermore, in March 2018 Raúl Gutiérrez - a Cuban national - was arrested in Colombia on suspicion of planning "to kill American diplomats on behalf of Islamic State (ISIS) extremists in the nation's capital of Bogotá."13 In part because of these plots and attacks U.S. politicians, popular media, and military leaders have increasingly come to see Latin America as part of the landscape of their global "War on Terror."

8 For example, in the run up to the 2012 U.S. Presidential election there was a Republican Primary debate, which focused on national security and foreign policy. Referring to the Triple Frontier region - a tri-border area along the junction of Paraguay, Argentina,

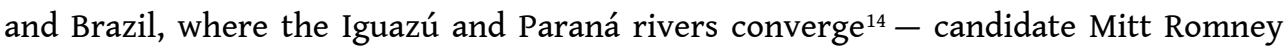
surmised that the supposed actions of Hezbollah - a Lebanon-based Shi'i Islamist political party and perceived terrorist group - in that region "pose a very significant and imminent threat to the United States. ${ }^{15}$ Without any cited evidence the other Republican candidates echoed Romney in quick succession. Rick Perry from Texas called for a renewed "twenty-first century Monroe Doctrine" to oppose radical Islamist incursions in the Americas and former senator Rick Santorum added, "I've spent a lot of time...[thinking] about what's going on in Central and South America. I'm very concerned about the militant socialists and the radical Islamists joining together, bonding together."16 Four years later, Donald Trump's presidential campaign and cabinet staff again rang the alarm about "sleeper cells" and imminent Hezbollah threats in Latin America. Gen. John Kelly - originally Mr. Trump's Director of Homeland Security and later his White House Chief of Staff - warned of a web of terror in South America coming from Shi'i and Sunni sources. However, as an article in The Nation pointed out, if these cells do exist then they must be "the sleepiest of sleeper cells." ${ }^{17}$ Nonetheless, it seems that U.S. politicians and presidential hopefuls see Latin America as a front in the "War on Terror" and have hinted at being willing to bring military force to bear on the situation and stem the tide of terror as it laps against the shores of their hemisphere.

The invocation of the "Monroe Doctrine" is especially relevant to this article's discussion. Beginning in 1823, the U.S. government wanted to prevent the incursion of European powers in the American hemisphere - what they saw as the young nation's own backyard. Since then, and even before, events in Latin America and the Caribbean have been concerns of U.S. national and foreign policy. There have been different specters hovering off the shores of the Americas in the minds of U.S. politicians - European powers, Marxist influences, Nazis, the Socialist-Communist, or other threats to U.S. economic and political interests in the region. At times, this has resulted in direct, and sometimes prolonged, military intervention and presence. While not an exhaustive list, the U.S. has involved itself in Puerto Rico (1898), Panama (1903-1914, 1989), the Dominican Republic (1903, 1905, 1916-1924, 1965-1967), Mexico $(1905,1917)$, Cuba (1906-1909, 1912, 1961), Honduras (1907), Nicaragua (1909, 1912-1925, 1926-1933, 
1984), Haiti (1915-1934), Grenada (1983), and Guatemala (1966, 1982-1983). The justification for these interventions was based on the premise that if foreign powers (for example, Europeans, Nazis, Communists) gained a foothold in the Americas it would endanger the peace, economic success, and political power of the U.S. in the region. U.S. politicians assumed their "partners" in Latin America and the Caribbean would not act as willful agents and choose such systems or ideologies, and thus the U.S. could assume that the introduction of ideas and systems contrary to their design in the region were tantamount to a foreign invasion and thus illegitimate. ${ }^{18}$ This is, at least in part how the U.S. viewed their intervention as an obligation or duty to their regional "partners." From the perspective of U.S. policy, these were unwanted foreign powers threatening the welfare of their Latin American and Caribbean neighbors and by extension the U.S. itself. The Monroe Doctrine helped first articulate this perspective and it remains a fundamental premise that could justify U.S. military intervention down to the present. ${ }^{19}$

While the U.S. has not proposed any direct military intervention in the region as a result of the global "War on Terror," the rhetoric of presidential candidates and some elected officials reflects a readiness to justify U.S. intervention in Latin American and Caribbean affairs in order to protect the region from the threat of the supposed foreign terrorist. The problem is, there is little to no verifiable evidence of large numbers of terror cells or violent-extremist organizations in the region. As R. Guy Emerson reflected, it is also possible that the "War on Terror" foreign-policy paradigm of the George W. Bush administration exacerbated a geostrategic disconnect between states in Latin America and the U.S. government. ${ }^{20}$ While I believe that there are states who are geostrategically allied with the "War on Terror" discourse and outlook, Emerson does well to point out how the Bush administration's interamerican relations were in many ways conformed to a broader "War on Terror" model. There is further evidence to show how the global "War on Terror" has shaped U.S. postures toward their neighbors to the South. In a research report for the Air Force Fellows Curtis C. Connell admitted that while there is not "a profound and deep history of Islamic terrorism in Latin America and the Caribbean" U.S. policy makers should remain vigilant concerning "Islamic fundamentalists activities in the region" because of "a more recent history of Islamic fundamentalists' support activities." ${ }^{21}$ In particular, he referenced the "TriBorder Area (TBA) between Argentina, Paraguay, and Brazil, which will be explored in more detail below.

11 Certain sectors of the have also traded in speculation about, and influenced popular and political views concerning, terror in Latin America and the Caribbean - most poignantly in the Trump era. In an op-ed for The Miami Herald Robert Singer - CEO and Executive Vice President of the World Jewish Congress - warned of letting terrorist groups fester in the region. He wrote of Hezbollah in particular that it "poses a serious danger to the entire civilized world" and it must be stopped "from building its strategic base in Central and South America."22 Furthermore, "the international community...must do everything possible to make sure that the Western Hemisphere does not become the next terrorist battleground." Others chimed in and suggested that the Trump administration should target, "Hezbollah's Latin American operations" specifically the "convergence of Iran-sponsored radical Islam with transnational organized crime in Latin America is a serious threat to the national security of the United States, especially in the tri-border area, or TBA..." ${ }^{23}$ Furthermore, citing the Grantham report for the National Center for Policy Analysis - a conservative American 
think-tank - Fox News led with a story about how "the growth of Islamic extremist activity in Latin America is a major security threat to our country. And Iran's influence in Latin America demands a new national security strategy in the region." ${ }^{24}$ The Grantham report, for its part, warned that "Islamists are organized, well-funded and operating sophisticated operations against the United States only a few hundred miles south of our border." ${ }^{25}$ Amidst this media fury over the threat of terror "south of our border," even those who believe that the threat is relatively low leave the door open and state that an attack based out of Latin America or the Caribbean is not only "possible; it may even be likely." Writing for the Christian Science Monitor Latin Americanist Christopher Sabatini wrote that the government should, "consolidate cooperation in the region" to "improve US security from radical Islam, from any source and from any region." ${ }^{26}$ All of these media speculations not only fan the flame of fear in the general public, but also make suggestions in regards to the policies and positions of U.S. officials and government leaders.

12 Two political cartoons also help tell this tale. The first, from October 2008, features an unfurled Mexican flag. Pulling back on the red portion on the bottom right-hand side of the flag is a turbaned and long-bearded individual who is made to look like a Taliban "terrorist" replete with menacing scowl and a lit-bomb in his hand and a kalishnikov rifle slung across his back. ${ }^{27} \mathrm{He}$ is a labeled, "JIHAD." Beyond drawing on Orientalist and Islamophobic stereotypes and motifs (modeled largely off the Taliban), this cartoon is meant to illustrate how jihadism is skulking in the background of Latin American nations. The other political cartoon from January 2017 shows two similarly stereotyped representations of the "Muslim terrorist" with bomb-in-hand and turban-on-head. ${ }^{28}$ This time, they are in the desert (signified by sandstone rocks and saguaro cacti) and being led by a "coyote" - a popular term for a people smuggler - across the U.S./ Mexico border. The terrorists comment to one another, "don't worry, they are still debating the immigration bill." Here, two hyper-nationalist policy concerns of the U.S. converge - immigration and terrorism.

The convergence of these two fears - that of the brown terrorist and the brown Latina/o coming from the south to invade the U.S. - have had an impact in U.S. politics. Not only do we see the evidence of this in the primaries of the 2012 Presidential election, but also in 2016 and the election of Donald Trump. He evinced a hard line on both. Far from fringe conspiracy theory, the two-pronged fear has given rise to a groundswell of voters who feel - like the authors quoted before - that the U.S. is under threat through a combination of potent perils. In this discourse, the fear of terrorists coming across the border amplifies an already potent racialized conception of the U.S.-Mexico border. The primary cause for the concern at the border is the fear that many in the U.S. have about Mexicans, Salvadorans, Guatemalans, and other immigrants. While terrorism is not the chief concern, it is added to the mix as more evidence in the case against "open borders." Related to this is the fear that "narco-traffickers" and "jihadists" will start to work together to threaten U.S. security at the borders. ${ }^{29}$ While this has yet to be translated into concrete policy, it is part of a broader spectrum of anti-immigrant rhetoric and illustrates a confluence of fears in U.S. politics and discussions around immigration.

14 These beliefs are undergirded by reports in the media that terror and terrains to the south are related in dangerous terms. For example, CNN falsely reported that there was a photo of the world-famous and popular Igauzu Falls found at an Al-Qaeda training 
camp in Afghanistan..$^{30}$ The media also regularly draws connections between Latin America and jihadist terror by invoking as many examples as they can and blaming the ability of terror to spread to the Americas via pathways in the south on things such as Venezuela's socialist government, the region's "horrendous prison system," or its "porous borders, transnational criminal organizations, sophisticated smuggling networks and the dubious ability of Latin American governments to detect and intercept terrorists." ${ }^{31}$ Unfortunately, there is scant evidence that so-called "radical Islamists" are lurking in the shadows of Latin America and the Caribbean or scurrying back-and-forth across the borders between the U.S. and the global south. ${ }^{32}$ If there are any, they have yet to make a significant impression or commit any attacks.

Even so, this has not stopped politicians, sectors of the media, and members of the military from discussing the potential, proposing policy, and advocating action to be taken against what they perceive as an imminent "threat." This new geography and iconography of terror that constructs Muslims as the "other" amidst the global "War on Terror" has extended its grip into Latin America and the Caribbean. In fact, some of the first extensive academic research in English on Islam and Muslim communities in Latin America and the Caribbean was carried out as part of the strategic training of U.S. military officials. Building off congressional hearings, first-hand research, demographic data, news media, and other publications these reports have tried to highlight the "complex interdependence" ${ }^{33}$ of state and non-state actors between the Middle East and Latin America and "determine whether U.S. national security interests should be more concerned about radical Islamic influence and support in Latin America and the Caribbean." ${ }^{34}$ Tracing the trajectories of various groups - from Hezbollah to Al-Qaeda to ISIS - these reports have come to differing conclusions. While one suggested that "the potential threat presented to the security of the U.S. and the Western Hemisphere from radical Islamic actors is serious and requires sustained attention from leaders in the region" ${ }^{35}$ another felt that "a mild level of concern" was justified, "but perhaps not to the heightened threat that some have suggested." ${ }^{36}$ Or, in other words, "keep your eyes on it, but don't overrate it." ${ }^{37}$ Despite this caution, it has been the former opinion - that of an imminent and dangerous threat - that has dominated the media and political discussion surrounding the amalgamation of terror and the Latin American and Caribbean regions.

This has led to the aforementioned "xenophobic state policies, new citizenship regimes, and racial and religious profiling" that Zine mentioned. From the Bahamas to Puerto Rico, Brazil to Mexico, Muslims across the Americas have felt the pressure of policies and public opinion bearing down on them. As Jerusa Ali wrote of Muslims in Brazil, "daily acts of religious expression, such as prayer, covering, and reciting in Arabic, have been reinscribed as suspicious and association with the acts of terrorists, a perspective reified by the media." ${ }^{38}$ Furthermore, in the wake of 9/11 the Mexican government increased security pressure and surveillance on the mosques and Muslim organizations in Mexico City and throughout the country. The effect has been that Arabs and Muslims - no matter their long-term presence in the various countries under consideration - have been conflated with terror. ${ }^{39}$ This point is underlined when situated within the U.S.'s historical role in the region. Similar to the ways that the U.S. heavily influenced the region with its geo-politics concerning European incursion or Communism so too the American-led "War on Terror" and its power-knowledge nexus has swayed how Latin American and Caribbean 
states approach the idea of terrorism or frame Islam and Muslim communities in their own countries and contexts. While Latin America and the Caribbean has its own Orientalist past that colors their treatment of the topic of Islam and Muslims, contemporary U.S. influence has stoked and fanned its flames. Edward Said introduced the idea of Orientalism through his publication of the same name in 1978, in which he probed the idea of the East and West as imagined antitheses to one another, through which the European West sought to dominate the "Orient" through a particular production of knowledge that posited that European identity was a progressive superior to the exotic and static "Orient." ${ }^{40}$ Although the concept of Orientalism was first applied to Europe's relations with the East, other regions such as Latin America have come under consideration and birthed new interpretations of what Orientalism is and how it operates. While there is disagreement about the degree to which Latin American and Caribbean power and knowledge regimes are "Orientalist," ${ }^{41}$ the region shares a long history of "other-ing" the Moor during Spanish colonization and the "Turco" immigrant from the 19th-century onward in law, literature, and society. ${ }^{42}$ Because of this, Muslim and Middle Eastern voices have often been marginalized and existed as "subaltern" groups in Latin American and Caribbean society. With that said, they have been able to find some voice in regimes that often free up political space for diverse subjects in an effort to differentiate themselves from European colonizers, but also from their indigenous pasts. Thus, in some way the Muslim and the Middle Eastern immigrants act as a kind of "middleman" minority in Latin American and Caribbean contexts. $^{43}$

18 All the same, because of the U.S.'s ability to sway Latin American and Caribbean politics and society through its foreign-policy emphases and global paradigms, Latin American Orientalism has been stoked along the way by its visions and vocabularies about Islam and Muslims. During the global "War on Terror," for example, the latent Orientalist fears of the "Turco" in Latin America or of the Muslim threat in the Caribbean have been configured so as to cast Islam and all Muslims as alien, exotic, and menacing. This dynamic will be underlined through the three examples to follow.

\section{The Question of Salafism, Jamaat al-Muslimeen, and Islam in Trinidad}

As much as ISIS is based in places such as Syria, Iraq, and Libya it still has transnational reach in its appeal, impact, and recruitment. One thing the global "War on Terror" has right is that jihadist Salafist groups like ISIS are able to operate across national boundaries and extend their influence across the globe. Beyond its claimed foreign attacks in Paris, London, New York, and other Western city-centers ISIS was also effective with recruitment of foreign fighters via agitprop and social media outreach. The top five countries they were able to recruit from include Tunisia, Saudi Arabia, Russia, Turkey, and Jordan. ${ }^{44}$ This is in terms of sheer numbers. When it comes to recruitment per capita among the Muslim population of respective countries, the top percentage of recruits comes from Finland, Ireland, Belgium, Sweden, Austria, and Trinidad and Tobago. ${ }^{45}$ This has led to speculation, and widespread concern, about the supposed rise of Salafism and radical jihadism among Trinidadian Muslims. With titles like, "ISIS in the Caribbean" and "Caribbean to Caliphate" several online news portals and print newspapers and magazines picked up on these numbers and began to report 
on the apparition of terror in Trinidad. ${ }^{46}$ There have been 89-125 Trinidadians total who reported for duty with ISIS. ${ }^{47}$ An article in The Atlantic pointed a finger at "the spread of Salafi Islam in the country" as one of the prime push factors for the departing fighters. ${ }^{48}$ This fear of the rise of jihadi-Salafism has led to Trinidadian Muslims being placed on terror "watch lists" and Caribbean Salafi scholars being detained across the globe. ${ }^{49}$

Salafism in Trinidad, let alone elsewhere, cannot be viewed as a "monolithic set of radical Islamic doctrines...implacably dedicated to violence" ${ }_{50}$ but instead must be understood according to further categories of delineation or a spectrum of opinion and implementation in multifarious contexts. ${ }^{51}$ The vast majority would be categorized as "purist" or "quietest" according to Wiktorowicz's categories. ${ }^{52}$ Their strength is not drawn from direct engagement with society, but a strategic withdrawal. ${ }^{53} \mathrm{As}$ MohamedAli Adraoui wrote, "the appeal of Salafi puritanism lies in its ability to provide a way of not only opting out of society but creating an alternative, superior community based on the unity of God." 54 This notion of withdrawal - or what Terje Østebø calls a "politics of withdrawal" ${ }_{55}$ - is particularly salient when considering Salafis in Trinidad.

Amidst the structural changes that occurred in Trinidad across the last several decades and in the wake of post-colonialism and immigration, new discourses focused on reform at the local, national, and global levels have created fresh ideological orientations among Muslims in the nation. These reform movements focus on an individualization and politicization of religious purity and a reconfiguring of authority. And so, some point the finger at poverty among Afro-Trinidadian Muslims as a reason for the rise in Salafism and for prompting the joining of groups such as ISIS. Al-Jazeera quoted Imam Yasin Abu Bakr, the leader of Jamaat al-Muslimeen, as saying that AfroTrinidadian Muslims are motivated to join ISIS because of their marginalization from society. He said, "they just sit in the ghetto and do nothing. And then drugs come in and it's a haven for the drugs. And now the guns are in and so the murder rate is just spiraling out of control." ${ }^{56}$

22 Jamaat al-Muslimeen started as a local Islamic group advocating for justice and reformation of Islamic religious life in the country. It drew its support from the ranks of urban Afro-Trinidadian poor in Port of Spain rather than among Syrian or South Asian Muslims in the country. Abu Bakr is a former police officer who resigned in 1968 and who converted to Islam in Canada. He returned to Trinidad with the aim of setting up Islamic da'wa, or mission, with urban youth. Drawing inspiration from the Nation of Islam and, by proxy, the Black Power Movement in the U.S. and the wider Caribbean Abu Bakr wanted to create a community set apart, which would empower its members and correct the wrongs of the wider society. And so, set apart a community he did. They set-up a compound on the outskirts of Port of Spain that included communal farming, shared resources, polygamous marriages, women in hijabs or full veils, and an overwhelmingly Afro-Trinidadian vibe among its members despite the presence of some Indo-Trinidadian youth and young adults. ${ }^{57}$

On the one hand, their withdrawal is an empowering move to join with other likeminded brethren. On the other hand, it signals a struggle to fit in with a society that seems to not accept you for who you are. In the case of Jamaat al-Muslimeen it also speaks to the underlying racial tensions that Afro-Trinidadian Muslims face when compared to their Indo-Trinidadian counterparts. Although withdrawal gives them some power, the members of Jamaat al-Muslimeen and Salafi groups in Trinidad (and 
those who are attracted to them) would rather recognition and respect in broader Trinidadian society. Lacking this, they withdraw or in some instances join the ranks of jihadist foreign fighters abroad. The son of the founder - Fuad - warned that while politicians may want to minimize or ignore this issue, the problem persists and grows larger. While certainly implicated in international currents of Salafism, jihadi violence, and the global "War on Terror" the previously cited articles also point to the very local issues that may motivate Trinidadian Muslims to travel and join ISIS's fight in Syria, Iraq, and elsewhere.

As we saw in the previous section, the link between Islam and terrorism is a major political, media, and military concern, especially since 9/11. This discourse has, according to Mahmood Mamdani, "turned religious experience into a political category, differentiating 'good Muslims' from 'bad Muslims' rather than terrorists from civilians. ${ }^{158}$ In no uncertain terms, Mamdani made clear that this leads to an attempted exorcism of Islamic threats and "bad Muslims" such as Salafis. This approach avoids historical contextualization and local issues and instead judges the situation on preconceived, boilerplate, benchmarks and biases. It follows, then, that analysts, researchers, and government officials are precluded from being able to see the practice of Islam as inherently intertwined with local issues surrounding gender, class, and other areas of social justice and societal concern. Thus, before jumping to any conclusions, it behooves us to pay attention to what is going on in Trinidad and understand the perceived increase in Salafism and ability for ISIS to recruit in the country within that country's particular historical and social context.

Trinidad and Tobago has one of the largest Muslim populations in the Caribbean around 78,000 or 6 per cent of the population - and is at times seriously divided between Asian immigrant communities and Afro-Trinidadian convert communities. Muslims on the island also live under the shadow of the 1990 Jamaat al-Muslimeen coup attempt, which ended after six days. Almost three decades later, "its memory has tarnished the image of the islands' Muslim community" ${ }^{59}$ and suspicion for various threats and trends is laid at the organization's - or the wider Muslim community's feet. For example, in 2011 the Trinidadian government declared a state of emergency following a spike in violent crime in Port of Spain - the nation's capital - and a possible assassination plot against then-Prime Minister Kamla Persad-Bissessar. Several members of the Afro-Trinidadian community were detained, including Abu Sa'd atTrinidadi, who would later rise to prominence via an interview in Dabiq, ${ }^{60}$ ISIS's now defunct online magazine. ${ }^{61}$ There was never any proof of their involvement and they never claimed to be planning the plot, but the suspicions linger. Even some scholars have jumped on the bandwagon of blame and accused the recruitment of ISIS fighters in Trinidad to "links with organized crime" (supposedly via Jamaat al-Muslimeen) and not to structural issues such as "tangible discrimination or lack of opportunity."62 While such structural issues impact large groups of people across the globe - the majority of which do not claim allegiance to any terror groups - it is important to pay attention to such issues when considering any minority resistance movement, Islamic or otherwise. Not doing so in this instance means the lack of a serious engagement with the story of Jamaat al-Muslimeen and their own experiences, efforts, and exploits over the years in the Trinidadian context.

26 Much of the discourse surrounding Jamaat al-Muslimeen circles back to their attempted coup in 1990. On 27 July 1990 a group of men from the group stormed the 
parliament in Port of Spain and a prominent television station and announced a new state based on a program of Islamic reform. Included among their hostages was the then-Prime Minister of Trinidad, A.N.R. Robinson and fifteen of his colleagues. From the station, Abu Bakr went to television and announced a popular people's revolution against the austerity measures and perceived injustices of the Robinson government. ${ }^{63}$ He cautioned the populace to not loot or destroy property. However, his warnings were ignored and mass looting and arson was unleashed soon after the announcement. Despite their strong hand and six-day holdout, Robinson and his government did not give into the group's demands and they started to lose control of the coup. ${ }^{64}$ Jamaat alMuslimeen then made an agreement with the government and surrendered. Twentyfour Trinidadians had died.

The coup was framed as part of a fundamentalist Islamic "holy war" in the media, which was exacerbated by the disillusionment and rage of AK-47 toting black young men who saw in Islam - and in their leader Abu Bakr - a play at power and prominence in Trinidadian society. ${ }^{65}$ In reality, the coup was predicated by a number of factors. Chris Searle argued that "Trinidad and Tobago presents a stark example of a recently decolonized nation that moved from relative underdevelopment to a form of superficial prosperity - due to the extraction and export of one particular raw material (petroleum)...only to be plunged back into poverty and dependence when the price of that raw material fell on the world market." ${ }^{66}$ There were also tensions over religious freedom to blame.

Just days before the attempted coup, Jamaat al-Muslimeen had lost a legal battle over their land in Port of Spain. While Eric Williams, the first Prime Minister of Trinidad, had bequeathed the land to Abu Bakr, the Robinson government had surveilled Jamaat al-Muslimeen and accused them of squatting on the land and being involved in organized crime. The Muslimeen, in turn, accused the government of harassment and false accusations. ${ }^{67}$ The attempted coup must be seen against this backdrop more than any "global holy war." For the members of the Muslimeen the coup, "represented a spark of resistance and hope of a way forward during a period when the community seemed rudderless and devoid of progressive leadership." ${ }^{68}$ The investigation into the coup never officially ended and Abu Bakr "continues to be a controversial figure and he and his group continue to be regarded as a threat to law and order in Trinidad and Tobago." ${ }^{69}$ His group, however, continue to live together separately in their compound, largely isolated from broader Trinidadian society. ${ }^{70}$ While the compound is tolerated by the government, it is still held in contempt and suspicion because of its isolation and because of the 1990 coup. Furthermore, members of Jamaat al-Muslimeen have always expressed a desire for their movement to be integrated more fully into its cultural environment in Trinidad.

Despite a general lack of evidence pointing to Jamaat al-Muslimeen members joining ISIS (in fact, it is reported that recruitment is coming from Rio Claro in the southeast, Chaguanas in central Trinidad, ${ }^{71}$ and Diego Martin, a small town north of Port of Spain) ${ }^{72}$ the coup in 1990 is linked together with 9/11, ISIS, and the global "War on Terror." While there may be some shared motivation and even a shared ideology in Salafism, the various events and exploits noted before are diverse, contradictory, ambivalent in relationship, and fragmented. In fact, Meijer pointed out how Salafism, for all its emphasis on unity, clarity, quiet activism, and universalism, is still undermined by regional fractures and hot-points of conflict dictated by local concerns 
and cues. ${ }^{73}$ Even if Jamaat al-Muslimeen should be considered a jihadi-Salafi movement, which I do not think is the best category to apply, it is important to "attempt to locate jihadism in local, national, and regional contexts" so as to have an "inside-out' perspective which can act as a corrective to those discussions of global jihadism which have been limited to identifying"74 how global actors (for example, Al Qaeda and ISIS) are exerting influence across the world. While they certainly have a role to play, it is the politics of marginalization, withdrawal, and recognition in Trinidadian society that seemed to exert the greatest influence on this group of Afro-Trinidadian Muslims.

In the end, whether it be the perception of the media or national governments or the inducements of individual actors and the transnational spread of ideas, men, and materials for the sake of jihad - the global "War on Terror" - cannot be seen as some unified, and universalized, global movement. While the aim of the American-led effort may be a unified global front against terror wherever it is found, the various states and organizations that participate in it may or may not comply with the U.S.'s rubric. Furthermore, as a term unmoored from its American inflections it can now be used as a phrase to address various local phenomena. This is seen when state leaders invoke the global "War on Terror" to address local groups, issues, and problems. Setting a local issue within the global "War on Terror" is meant to justify greater uses of force, encourage the support of other nation-states, and stoke feelings of a need for unity against a common enemy. This runs parallel to the ways in which local states invoked the global struggle against Communism during the Cold War in order to coax broader support for their local competitions for power. In order to analyze the global "War on Terror," properly we must not only recognize its global and amalgamating aspects, but see how the global and the local are engaged in a dynamic dance of push and pull factors and multifarious motivations at various registers. The example illustrated before shows how a Caribbean context (Trinidad) is implicated in, and influenced by, ISIS's global war. It also illustrated how the assumptions of the global "War on Terror" have framed, and continue to influence the interpretation of, what was largely a local incident - the 1990 coup. The situation is similar for Argentine Muslims in the public sphere.

\section{The Tenuous Place of Muslims in Argentina's Public Sphere}

31 When President Mauricio Macri made his comments about committing to fight terrorism "head to toe" he not only had in mind the most recent attacks in New York, but also two earlier attacks that came to frame the place of Islam and Muslims in the Argentine public sphere. That place is a tenuous one, to be sure. Although the Muslim community in Argentina is relatively strong, and has a history stretching back to the sixteenth century, Muslims still suffer from anti-Arab sentiment and a storm of suspicion swirling around them in relation to attacks on Argentine soil and the broader discourse of the global "War on Terror." There is no firm conclusion on the current number of Muslims in Argentina. ${ }^{75}$ Despite the inconclusiveness concerning numbers, Islam came to the foreground of the Argentine public sphere with the election of Carlos Menem to the top office in Argentina. Born to Syrian Muslim immigrants, Menem converted to Catholicism in 1966 in hopes of attaining public office. ${ }^{76}$ Despite his efforts at showcasing his Catholicism he was regularly labeled during his ten-year presidency 
(1989-1999) a "Turco" and his government was referred to as the "Harem Government." The failure of his governmental ability was then misappropriated to his Muslim upbringing by many.

This negative view of Muslims was exacerbated by the bombing of the Israeli embassy in Buenos Aires on 17 March 1990 when twenty-two people were killed. A few years later, the Jewish Community Center of Buenos Aires was attacked on 18 July 1994 with eighty-five people being killed and 300 people injured. These two events damaged the image of Muslims in Argentina. While the physical effects of the bombings left little to be remembered and there are no visible scars in the city of Buenos Aires, memories of terror still linger in the air and lead to tension over the place of Muslims in Argentine culture and public life. The fact that the investigation has not been settled is still a potent political issue in Argentina.

33 Argentina has a large Jewish population, ${ }^{77}$ which at 300,000 people is the largest in Latin America and has maintained generally positive relations with the nation of Israel over the years. Hence, some surmise, this has made them a target of Muslim extremists and pro-Palestinian terror groups. ${ }^{78}$ Indeed, the Islamic Jihad Organization (IJO, also known as "Islamic Jihad") as Shi'i militia in Lebanon claimed responsibility for the bombing of the Israeli embassy in $1990 .{ }^{79}$ However, the investigation into the AMIA bombing has taken over twenty years and has been mired in controversy and subterfuge. In 2006, Argentine prosecutors charged eight Iranian government officials with orchestrating and executing the attack. ${ }^{80}$ Iranian diplomat Mohesen Rabbani was singled out for taking lead in planning the bombing. Red alerts were issued by Interpol, at the behest of the lead prosecutor and prominent member of the Argentine Jewish community - Alberto Nisman. Nisman claimed his investigation and prosecution were constantly being hampered by both former president Nestór Kirchner and his wife, and former president, Cristina Fernández de Kirchner in exchange for political favors and economic agreements with Iran. Nisman died due to a bullet wound to the head in his apartment in January 2015. There is no conclusive evidence to point to whether his death was a suicide, a forced suicide, or a murder. In September 2017, there were reports that concluded he was murdered, but suspicion and intrigue still swirl around his death.

When Macri ran for President in 2015 he capitalized on the controversy between de Kirchner and the Nisman case. Riding a wave of popular sentiment that felt "Islamic fundamentalism" ${ }^{81}$ was to blame for Nisman's death and that de Kirchner was working with Iran to cover up their involvement in the AMIA incident and Nisman's supposed assassination, Macri vowed to achieve justice. He also promised to take up the fight against "radical Islam." After he was elected, one of his first actions was to void a "memorandum of understanding" that allowed Iran to undertake its own investigation of those accused in the AMIA bombing. ${ }^{82}$ Furthermore, for the first time in twenty-six years, the Argentine government took a formal role in commemorating the AMIA bombing. What is extraordinary here is not that the Macri government did so, but that no previous government had done so. Argentina's Vice President Gabriela Michetti said at the event, "[t]oday we have decided to remember here, as a symbol that this is a top priority issue in the government's human rights agenda." 83 Some commentators have taken this as evidence of a paradigm shift in Argentine politics and public opinion. And yet, if we keep the longue durée and broader scope of worldwide political currents in mind we also see this is in keeping with Argentina's own long-held Orientalist and anti- 
Arab past. This historical frame of mind has only been exacerbated after the 1990 attacks and the speculation surrounding them, 9/11, and the the post-ISIS uptick in tough, and unrelenting, language as part of the global "War on Terror."

\section{Fear and Terror Along the Triple Frontier}

The nebulous reputation and position of Muslims in Argentina is exacerbated by the rumors that surround the Triple Frontier region where Argentina, Paraguay, and Brazil meet. As alluded to earlier, this region has been surrounded by speculation as a safehaven for foreign terrorists and sleeper cells over the last two to three decades. Rather than being a place ripe for fear and trembling, it has instead been a place of significant economic success for many Lebanese immigrants and their families. As I will argue in this final section, it is perhaps a confluence of fears of terror and a long-lingering disquiet about frontiers in the Americas that constitutes the qualms about this quarter of the Latin American landscape.

The geographical boundary of the Triple Frontier is set by the confluence of the Paraná and Iguaçu rivers where Argentina, Brazil and Paraguay meet. There are three cities connected to each other by bridges across this frontier. In Paraguay is Ciudad del Este, founded in 1957 as Puerto Presidente Stroessner. On the other side of the bank of Rio Paraná lays the Brazilian city of Foz do Iguaçu bordering Argentine Puerto Iguazu. The preferred migratory destination for many immigrants has traditionally been either Foz do Iguaçu or Ciudad del Este since Puerto Iguazu was never fully integrated into the local economy ${ }^{84}$ The area has long been associated with violence, crime, and terrorism. Instead of being known for economic development, ethnic and religious diversity, and immigrant integration into the local community the area became known as a "notorious border zone." ${ }_{85}$ In fact, in 2019 the entertainment company Netflix released a blockbuster-style movie about drug trafficking and crime in the area, titled, "Triple Frontier." ${ }^{86}$ Part of this is surely associated to the real threat associated with smuggling, drug trafficking, and other unmonitored trans-border activity in the past. Still, there is zero firm evidence that the Triple Frontier is presently a "hive of activity" for terrorist groups. Instead, the media, military, and policy makers have constantly quoted one another in a "closed loop of self-references" to the effect of producing wild allegations about Osama Bin Laden's presence in the area or that, as CNN incorrectly reported, that Al-Qaeda had pictures of Iguaçu Falls hidden away in their files in Afghanistan.$^{87}$ Even some scholars have contributed to this loop without any adequate citation or proof. ${ }^{88}$ Connell reported to the U.S. Airforce that, "the large Arab community in the [Tri-Border Area] is highly conducive to using the region for the establishment of sleeper cells" and that it features the "largest concentration of Islamic extremists in Latin America." 89

However, as Karam pointed out, these potent fears and estimates are overblown. Instead, an unhealthy dose of anti-Semitism, Orientalism, Islamophobia, and anti-Arab sentiment has festered in Argentina and elsewhere and claimed the Lebanese diaspora community at the Triple Frontier as its victims..$^{90}$ Combined with Argentina's history of anti-Arab and Orientalist attitudes ${ }^{91}$ more recent concerns over terror and security accusations soon emerged suggesting that the Triple Frontier was a "hive of activity for Middle-Eastern 'terrorist' groups, which could use the region as a base from which to 
attack." ${ }^{92}$ As referenced earlier, this claim got caught up in the U.S.-led global "War on Terror" and became a talking point for conservative politicians in the United States.

I would also like to suggest that the fears swirling around the Triple Frontier and its Lebanese-Muslim community are part of long-held American feelings about the frontier, which have come to influence other regional and national opinions about the area. As colonists and settlers moved westward across the North American continent there emerged a complex consciousness of what the frontier entailed. This consciousness, the historian Frederick Jackson Turner argued, ${ }^{93}$ was the single most important factor in shaping a distinctly American character and in differentiating America from its European forebears. The frontier - that contact zone between European settler and wild, open land, of savages and wilderness, transformed the European sentiment and "stripped off the garments of civilization." The newly minted American man then transformed the wilderness not with derivative forms of European civilization, but a new, and distinctly, American one that was more democratic and non-authoritarian. Turner's "Frontier Thesis" and its view of a hopeful, triumphant, frontier came to dominate American history for decades until challenged by Patricia Nelson Limerick, ${ }^{94}$ among others. It also prevailed in popular culture (look no further than the Canadian series "Little House on the Prairie") and in U.S. politics.

As Turner surmised, with the transcontinental dream and the "Manifest Destiny" of the United States deemed complete in the conquering of the continental divide it could be said that the frontier was closed. However, it is also possible that the U.S. has sought new frontiers through its later acquisitions of colonies and states in the Pacific Rim, Asia, and the Caribbean. In addition, their efforts against the "communist hordes" of the U.S.S.R. and its satellite states could be seen as the U.S. turning to other frontiers to concur or defend in the late twentieth century - including space, the so-called "final frontier." During the Cold War frontiers in places where "communism met democracy" became the crucible for the making or breaking of the "American way." Part of this frontier geography included Latin America where - as mentioned above - the U.S. involved itself in state politics and supported violent measures to protect its interests in the region. After the end of the Cold War in the 1990s what frontiers were there left to conquer, settle, and civilize? The global "War on Terror" could be read as a form of the "frontier spirit" in American culture and politics. In this view, the Middle East, "the Muslim World," and possibly even geographies such as the Triple Frontier area are imagined as the new borderlands where American democratic culture and its freespirit of class consciousness and anti-authoritarianism must settle and tame.

There are parallels in how the U.S. and its allies have recast local frontiers in the American hemisphere as part of the broader global "War on Terror." This has produced an inordinate amount of fear and loathing about frontiers and "bloody borders" 95 where policy makers, pundits, and wider publics are concerned that Islam is seeping through porous boundaries and into supposedly Western-Christian lands. These "bloody borders" are found between Kenya and Somalia, Indonesia and Malaysia, Turkey and the Balkans. We should also consider the borderlands between Mexico and the U.S., the liminal islands and landscapes of the Caribbean, and places such as the Triple Frontier zone as part of this new American "frontier" geography as well. Here again, U.S. politicians are seeking to extend their supposedly civilizing reach to a place supposedly festering with terrorism and anti-American sentiment. Air Force Fellow Curtis Connell referred to the "Tri-Border" area as a "wild west'...between Argentina, 
Brazil, and Paraguay," ${ }^{96}$ and made clear that the Islamist fund raising he reported was going on there had a clear "connection to what's happening in the Middle East" and required "extra surveillance and increased attention by the U.S. in cooperation with Latin American partners [to] help control the problem" ${ }^{97 "}$ and counteract the "loose rule of law even by Latin American standards" there. ${ }^{98}$ As referenced earlier, this kind of "frontier" framing and policy recommendations such as Connell's have led some presidential candidates to invoke the "Monroe Doctrine," which includes the possibility of military force in places such as the Triple Frontier if necessary.

\section{Conclusion}

The kind of irrational and prejudicial fear described above in U.S., Latin American, and Caribbean media, politics, and society is often called "Islamophobia." Islamophobia emerges out of long-held biases against Muslims in the Americas and elsewhere. "Orientalism," Todd Green reminds us, "is the breeding ground of Islamophobia." While both Orientalism and Islamophobia have long plagued Latin America, the Caribbean, and the Americas as a whole, ${ }^{100}$ they have grown significantly across the hemisphere in the wake of $9 / 11$ and the subsequent launch of the global "War on Terror." This "war," with its global reach and blatant breaching of human rights for the sake of security and safety has fostered a social context in which Islamophobia thrives across the region. Negative stereotypes about Muslims continue to worsen as the U.S. and its allies continue to attempt to monitor and neutralize terror threats around the globe - including in places such as Argentina, the Triple Frontier, and Trinidad. Shaped by a longer history, ${ }^{101}$ American Islamophobia is not produced by any one politician, party, or country. Nonetheless, the positions taken by American politicians, think-tanks, and regional bodies have an impact on the local lives of Muslims living in the Americas - whether they be in Buenos Aires, Port of Spain, or Puerto Iguazu. While Arabs, Muslims, and others under the spotlight may find economic success, they also report sentiments of marginalization and suspicion by their fellow citizens. Although affluent or accepted in some respects, their place in the societies they call home is frequently called into question.

Nonetheless, it isn't just 9/11, ISIS, Jamaat al-Muslimeen, supposed terrorists in the borderlands of Latin America, or truck attacks in New York that have made things the way they are. These concerns represent old anxieties about Islam and Muslims that have been inherited from the past and have continued to fester in recent years. With all of this in mind, this paper has tried to explain how the tenuous place of Muslims in Latin American and Caribbean public spheres must be considered in light of a complex nexus of various factors including, but not limited to, local politics and public sentiments, historical events and communities in the region, and the broader context of the global "War on Terror" and the continuing outsized influence of the U.S. in the Americas as a whole. It seems that for all that has occurred over the last five centuries since Muslims first became part of the American story, little has changed. Because of these various inter-related factors, Muslims in the Americas continue to be received, perceived, refashioned, integrated (or not) into Latin America, the Caribbean, and the broader hemisphere along old discourses of identity and difference. We do well to remember that it is a combination of contemporary global and regional fears, politics, 
and rhetoric combined with local and historical factors that play into how Muslims are so-often tailored, and treated, as the "other" in the Americas and beyond.

\section{BIBLIOGRAPHY}

"10 more criminal cases that highlight Islamic terror threat at US-Mexico border," https:// creepingsharia.wordpress.com/2017/01/30/10-cases-border-terror/ [last accessed 7 April 2018].

ADRAOUI, Mohamed-Ali, "Salafism in France: Ideology, Practices and Contradictions”, in Global Salafism: Islam's New Religious Movement, ed. Roel Meijer, Oxford, Oxford University Press, 2013, pp. 364-383, DOI:10.1093/acprof:oso/9780199333431.003.0017. https:// oxford.universitypressscholarship.com/view/10.1093/acprof:oso/9780199333431.001.0001/ acprof-9780199333431-chapter-17

ALEXANDER, Harriett, "The Buenos Aires bomb, the Iranian allegations, and the accusations against Cristina Kirchner," https://www.telegraph.co.uk/news/worldnews/southamerica/ argentina/11356031/The-BuenosAires-bomb-the-Iranian-allegations-and-the-accusationsagainst-Cristina-Kirchner.html [last accessed 28 April 2018].

ALI, Jerusa, "Bahamian and Brazilian Muslimahs: Struggle for Identity and Belonging," in Islam and the Americas, ed. Aisha Khan, Gainesville, University Press of Florida, 2015, pp. 186-214.

"Argentina co-sponsors memorial for attack on Israeli embassy," http:// www.israelnationalnews.com/News/News.aspx/243324 [last accessed 28 April 2018].

BADRI-MAHARAJ, Sanjay, "Globalization of the Jihadist Threat: Case Study of Trinidad and Tobago”, Strategic Analysis, 14.2 (2017), pp. 173-189.

BAHGAT, Karim, MEDINA, Richard M., “An Overview of Geographical Perspectives and Approaches in Terrorism Research", Perspectives on Terrorism, 7.1 (2013), pp. 38-72.

BAPTISTE, Jeanne, "More than Dawud and Jalut: Decriminalizing the Jamaat al Muslimeen and Madressa in Trinidad", in Islam in the Americas, ed. Aisha Khan, Gainesville, University Press of Florida, 2015, pp. 269-295.

BEZHAN, Frud, "Explainer: Iran's Alleged Part In 1994 Bombing of Buenos Aires Jewish Center," https://www.rferl.org/a/iran-argentina-bombing-jewish/25004062.html [last accessed 28 April 2018].

BREMMER, Ian, "The Top 5 Countries Where ISIS Gets Its Foreign Recruits," http://time.com/ 4739488/isisiraq-syria-tunisia-saudi-arabia-russia/ [last accessed 28 April 2018].

BRIEGER, Pedro, HERSKOWICH, Enrique, “The Muslim Community of Argentina”, The Muslim World, 91.1 (2002), pp. 157-168, https://doi.org/10.1111/j.1478-1913.2002.tb03738.x.

CAMAYAD-FREIXAS, Erik, Orientalism and Identity in Latin America Fashioning Self and Other from the (Post)Colonial Margin, Tucson, University of Arizona Press, 2013.

CARABALLO-RESTO, Juan F., Palestinian Muslims as a 'Middle-Man Minority Group' in San Juan, Puerto Rico, BA Thesis, San Juan, University of Puerto Rico, 2003. 
“Caribbean to Caliphate," https://www.aljazeera.com/programmes/peopleandpower/2017/05/ caribbeancaliphate-170517073332147.html [last accessed 28 April 2018].

CHANDLER, Michael, GUNARATNA, Rohan, Countering Terrorism: Can We Meet the Threat of Global Violence?, London, Reaktion Books, 2007.

CIVANTOS, Christina, Between Argentines and Arabs: Argentine Orientalism, Arab Immigrants, and the Writing of Identity, Albany, NY, State University of New York Press, 2006.

CNN, "Full Transcript of CNN National Security Debate," November 22, 2011 http:// transcripts.cnn.com/TRANSCRIPTS/1111/22/se.o6.html, [last accessed 7 March 2018].

CONNELL, Curtis, Understanding Islam and its Impact on Latin America, Maxwell Air Force Base, Air Force Fellows, 2005.

CONNELL-SMITH, Gordon, The United States and Latin America, London, Heinemann Educational Books, 1974.

COTTEE, Simon, "ISIS in the Caribbean," https://www.theatlantic.com/international/archive/ 2016/12/isistrinidad/509930/ [last accessed 28 April 2018].

Dābiq Magazine, 5, http://jihadology.net/category/dabiq-magazine/ [last accessed 28 April 2018]. DEOL, Jeevan, KAZMI, Zaheer (eds.), Contextualizing Jihadi Though, New York, Columbia University Press, 2011.

DIETZ, James L., "Destabilization and Intervention in the Caribbean", Latin American Perspectives, 11.3 (1984), pp. 3-14.

DUBOWITZ, Mark, DERSHOWITZ, Toby, “Iranian Terror. Argentinian Cover Up. Justice at Last?”, https://www.nytimes.com/2017/12/11/opinion/argentina-kirchner-iran-nisman.html [last accessed 28 April 2018].

ELKIN, Judith Laikin, The Jews of Latin America, Boulder and London, Lynne Rienner Publishers, 2014.

ELLIS, R. Evan, "Radical Islam in Latin America and the Caribbean: Implications for U.S. National Security," http://www.dtic.mil/dtic/tr/fulltext/u2/a618995.pdf [last accessed 19 March 2018].

ELMALEH, Omri, “The Lebanese-Muslim Diaspora in the Triple Frontier (Argentina, Brazil and Paraguay)", in Encyclopedia of Latin American Religions, ed. Henri Gooren, Berlin, Springer, 2017, pp. 870-872.

EMERSON, Ronald Guy, "Radical Neglect? The 'War on Terror' and Latin America”, Latin American Politics and Society, 52.1 (2010), pp. 33-62.

"Fear and Islam in Trinidad," https://dialogo-americas.com/en/articles/fear-and-islam-trinidad [last accessed 28 April 2018].

FLEMING Jr., Mike “'Triple Frontier' Finally Going: Affleck, Isaac, Pascal, Hunnam, Hedlund, Arjona In JC Chandor's Lineup," http://deadline.com/2018/03/triple-frontier-movie-ben-affleckoscar-isaac-pedropascal-charlie-hunnam-garrett-hedlund-adria-arjona-jc-chandornetflix-1202345230/ [last accessed 28 April 2018].

FLORIDA, Richard, “The Geography of Foreign ISIS Fighters," https://www.citylab.com/equity/ 2016/08/foreign-fighters-isis/493622/ [last accessed 28 April 2018].

FUKUYAMA, Francis, The End of History and the Last Man, New York, Free Press, 1992. 
GOLD, Danny, "The Islamic Leader Who Tried to Overthrow Trinidad Has Mellowed... a Little", https://news.vice.com/article/the-islamic-leader-who-tried-to-overthrow-trinidad-hasmellowed-alittle [last accessed 7 April 2018].

GRANDIN, Greg, “About Those Islamist Sleeper Cells in South America...," https:// www.thenation.com/article/about-those-islamist-sleeper-cells-in-south-america/ [last accessed 11 April 2018].

HAAR, Jerry, "Radical Islam's Latin American connection,” http://www.miamiherald.com/ opinion/oped/article46127140.html [last accessed 17 March 2018].

HILL, James, "Building Security Cooperation in the Western Hemisphere," remarks at NorthSouth Center, 3 March 2003, http://www.iwar.org.uk/news-achieve/2003/03-12/htm [last accessed October 1, 2018].

HUNTINGTON, Samuel P., The Clash of Civilizations and the Remaking of World Order, New York, Simon and Schuster, 2002.

"I'm no ISIS Point Man: Yasim Abu Bakr," https://www.trinidadexpress.com/news/im-no-isis-point-man279688692.html [last accessed 7 April 2018].

"In New York the Deadliest Terrorist Attack Since 9/11 Stirs Old Memories and Strengthens Resolve," https://www.washingtonpost.com/world/national-security/in-new-york-thedeadliest-terrorist-attack-since911-stirs-old-memories-and-strengthens-resolve/2017/11/01/ b6cdaf62-bf39-11e7-97d9- bdab5a0ab381_story.html?utm_term=.370316bc4780 [last accessed 1 April 2018].

"Islam and the Global War on Terrorism in Latin America," http://www.pewforum.org/ 2006/04/06/islamand-the-global-war-on-terrorism-in-latin-america/ [last accessed 28 April 2018].

KARAM, John Tofik, “Anti-Semitism from the Standpoint of its Arab Victimsin a South American Border Zone", Latin American and Caribbean Ethnic Studies, 6.2 (2011), pp. 143-167.

KARAM, John Tofik, "Crossing the Americas: The U.S. War on Terror and Arab Cross-Border Mobilizations in a South American Frontier Region", Comparative Studies of South Asia, Africa, and the Middle East, 31.2 (2011), pp. 251-266.

KOPP, Jason, "As Islamic extremism grows in Latin America, some want Trump to take action," Fox News, April 25, 2018, https://www.foxnews.com/us/as-islamic-extremism-grows-in-latinamerica-some-wanttrump-to-take-action, [last accessed October 1, 2018].

KRYT, Jeremy, "Inside the ISIS Plot to Kill Americans in Colombia," https:// amp.thedailybeast.com/inside-theisis-terror-plot-to-kill-us-diplomats-in-colombia [last accessed 7 April 2018].

KUSUMO, Fitra Ismu, Islam en América Latina. Tomo II: Migración Árabe a América Latina, Ciudad de México, Rumah Jade Production, 2013.

LIMERICK, Patricia Nelson, The Legacy of Conquest: The Unbroken Past of the American West, New York, Norton and Company, 1987.

MAMDANI, Mahmood, “Good Muslim, Bad Muslim: A Political Perspective on Culture and Terrorism”, American Anthropologist, 104.3 (2002), pp. 766-775.

McCOY, John, KNIGHT, W. Andy, "Homegrown Violent Extremism in Trinidad and Tobago: Local Patterns, Global Trends", Studies in Conflict and Terrorism, 40.4 (2017), pp. 267-299. 
MEIJER, Roel, “Introduction”, in Global Salafism: Islam's New Religious Movement, ed. Roel Meijer, Oxford, Oxford University Press, 2013.

MENDIETA, Eduardo, "Ni Orientalismo ni Occidentalismo: Edward W. Said y el Latinoamericanismo", Tabula Rasa, 5 (2006), pp. 67-83.

NAGY-ZEKMI, Silvia (ed.), Moros en la Costa: Orientalismo en Latinoamérica, Madrid: Iberoamericana, 2008.

"Official Statement of Dr. Bilal Philips on his Arrest in Phillippines," https://muslimmatters.org/ 2014/09/13/official-statement-bilal-philips-arrest-philippines/ [last accessed 28 April 2018].

OTTOLENGHI, Emanuele, "Hezbollah in Latin America is a threat the US cannot ignore," The Hill, https://thehill.com/blogs/pundits-blog/homeland-security/337299-hezbollah-in-latin-americais-a-securitythreat-the-us [last accessed October 1, 2018].

“'Overseas Contingency Operation'". http://www.washingtonpost.com/wpdyn/content/article/ 2009/03/24/AR2009032402818.html [last accessed 1 April 2018].

PANTIN, Raoul A., Days of Wrath: The 1990 Coup in Trinidad and Tobago, Lincoln, iUniverse, 2007.

PERSAUD, Prea, "Islam in Trinidad", in Encyclopedia of Latin American Religions, ed. Henri Gooren, Berlin, Springer, 2019, pp. 647-652, DOI: https://doi.org/10.1007/978-3-319-08956-0_267-1

QAMBER, Rukhsana, “Anti-Islamic Bias in Sources on Latin America: Preliminary Findings”, Islamic Studies, 42 (2003), pp. 651-685.

QAMBER, Rukhsana, “Inquisition Proceedings against Muslims in 16th Century Latin America”, Islamic Studies, 45 (2006), pp. 21-57.

ROBLES, Frances, “Trying to Stanch Trinidad's Flow of Young Recruits to ISIS," https:// www.nytimes.com/2017/02/21/world/americas/trying-to-stanch-trinidads-flow-of-youngrecruitsto-isis.html [last accessed 28 April 2018].

ROGOZEN-SOLTAR, Mikaela, "Managing Muslim Visibility: Conversion, Immigration, and Spanish Imaginaries of Islam”, American Anthropologist, 114 (2012), pp. 611-623.

SABATINI, Christopher, "Is there a credible Islamist threat in Latin America?", The Christian Science Monitor, January 29, 2017 https://www.csmonitor.com/World/Americas/Latin-AmericaMonitor/2017/0129/Is-therea-credible-Islamist-threat-in-Latin-America [last accessed October 2, 2018].

SAID, Edward, Orientalism, New York, Vintage Books, 1978.

SEARLE, Chris “The Muslimeen Insurrection in Trinidad”, Race \& Class, 33.2 (1991), pp. 29-43.

SILLS, M. David, BAGGETT, Kevin, "Islam in Latin America", Southern Baptist Journal of Theology, 15.2 (2011), pp. 28-41.

SINGER, Robert, "With roots in Latin America, Hezbollah is the real terror threat in our hemisphere," The Miami Herald, May 10, 2018, https://www.miamiherald.com/opinion/oped/ article210889749.html\#storylink=cpy last accessed October 1, 2018].

TAUB, Emmanuel, Otredad, orientalidad e identidad: Nociones sobre la construcción de un otro oriental en la revista Caras y Caretas. 1898-1918, Buenos Aires, Teseo, 2008.

“The Latest: Argentine President Reacts to Bike Path Attack," https://www.usnews.com/news/ beststates/new-york/articles/2017-11-01/the-latest-argentine-president-reacts-to-bike-pathattack [last accessed 1 April, 2018]. 
"The Secular Roots of Radical Political Islam An Essay by Mahmood Mamdani," http:// www.middleeasteye.net/essays/how-terrorism-useful-ourgovernments-112174807 [last accessed 1 April 2018].

WEBSTER, Michael, "Hezbollah and Mexica Drug Cartels Operating in Mexico and U.S.”, http:// banderasnews.com/0810/edat-mexhezbollah.htm [last accessed 11 April 2018].

WEISS, Michael, ISIS: Inside the Army of Terror, New York, Regan Arts, 2016.

WIKTORIWICZ, Quintan, “Anatomy of the Salafi Movement”, Studies in Conflict and Terrorism, 29 (2006), pp. 207-239.

ZINE, Jasmin, "Unsettling the Nation: Gender, Race and Muslim Cultural Politics in Canada", in Islam in the Hinterlands: Muslim Cultural Politics in Canada, ed. Jasmin Zine, Vancouver, UBC Press, 2012, pp. 41-60.

\section{NOTES}

1. “The Latest: Argentine President Reacts to Bike Path Attack," https://www.usnews.com/news/ best-states/new-york/articles/2017-11-01/the-latest-argentine-president-reacts-to-bike-pathattack, last accessed 1 April, 2018.

2. "In New York the Deadliest Terrorist Attack Since 9/11 Stirs Old Memories and Strengthens Resolve," https://www.washingtonpost.com/world/national-security/in-new-york-thedeadliest-terrorist-attack-since-911-stirs-old-memories-and-strengthens-resolve/2017/11/01/ b6cdaf62-bf39-11e7-97d9-bdab5a0ab381_story.html?utm_term=.370316bc4780, last accessed 1 April 2018.

3. Frances Martel, “Argentina, Home to Deadliest Jihad in Hemisphere Before 9/11, Struck Again in NYC," http://www.breitbart.com/national-security/2017/11/01/argentina-home-worstterror-attack-hemisphere-911-struck-nyc/, last accessed 1 April 2018.

4. Calling something "terrorism" is not necessarily a means of identification of a plain thing, but instead a discourse of power that happens to be very useful for governments to frame their wars as something for the common good. Once a government is going after "terrorists" it is much easier to justify physical force, the suspension of rules of war, and blatant crimes against humanity. See "The Secular Roots of Radical Political Islam An Essay by Mahmood Mamdani," http://www.middleeasteye.net/essays/how-terrorism-useful-our-governments-112174807, last accessed 1 April 2018.

5. Or its euphemisms like, “'Overseas Contingency Operation'". http:// www.washingtonpost.com/wp-dyn/content/article/2009/03/24/AR2009032402818.html, last accessed 1 April 2018.

6. Karim Bahgat and Richard M. Medina, "An Overview of Geographical Perspectives and Approaches in Terrorism Research", Perspectives on Terrorism 7-1 (2013), pp. 38-72.

7. Michael Chandler and Rohan Gunaratna, Countering Terrorism: Can We Meet the Threat of Global Violence?, London, Reaktion Books, 2007, p. 13.

8. M. Chandler and R. Gunaratna, Countering Terrorism ..., p. 14.

9. Samuel P. Huntington, The Clash of Civilizations and the Remaking of World Order, New York, Simon and Schuster, 2002.

10. Francis Fukuyama, The End of History and the Last Man, New York, Free Press, 1992.

11. Jasmin Zine, "Unsettling the Nation: Gender, Race and Muslim Cultural Politics in Canada", in Islam in the Hinterlands: Muslim Cultural Politics in Canada, ed. Jasmin Zine, Vancouver, UBC Press, 2012, p. 43.

12. J. Zine, “Unsettling the Nation ...”, p. 272. 
13. Jeremy Kryt, "Inside the ISIS Plot to Kill Americans in Colombia," https:// amp.thedailybeast.com/inside-the-isis-terror-plot-to-kill-us-diplomats-in-colombia, last accessed 7 April, 2018.

14. We will discuss the Triple Frontier region and its role in the discourse surrounding the global "War on Terror" later in the article, in the section on Argentina.

15. CNN, "Full Transcript of CNN National Security Debate," November 22, 2011 http:// transcripts.cnn.com/TRANSCRIPTS/1111/22/se.o6.html, last accessed 7 March 2018.

16. Idem.

17. Greg Grandin, "About Those Islamist Sleeper Cells in South America...," https:// www.thenation.com/article/about-those-islamist-sleeper-cells-in-south-america/, last accessed 11 April 2018.

18. See James L. Dietz, "Destabilization and Intervention in the Caribbean", Latin American Perspectives 11-3 (1984), pp. 3-14.

19. Gordon Connell-Smith, The United States and Latin America, London, Heinemann Educational Books, 1974, p. 62.

20. Ronald Guy Emerson, "Radical Neglect? The 'War on Terror' and Latin America", Latin American Politics and Society 52-1 (2010), pp. 33-62.

21. Curtis Connell, Understanding Islam and its Impact on Latin America, Maxwell Air Force Base, AL, Air Force Fellows, 2005, p. 30.

22. Robert Singer, "With roots in Latin America, Hezbollah is the real terror threat in our hemisphere," The Miami Herald, May 10, 2018, https://www.miamiherald.com/opinion/op-ed/ article210889749.html\#storylink=cpy, accessed October 1, 2018.

23. Emanuele Ottolenghi, "Hezbollah in Latin America is a threat the US cannot ignore," The Hill, https:/thehill.com/blogs/pundits-blog/homeland-security/337299-hezbollah-in-latin-americais-a-security-threat-the-us, accessed October 1, 2018.

24. Jason Kopp, "As Islamic extremism grows in Latin America, some want Trump to take action," Fox News, April 25, 2018, https://www.foxnews.com/us/as-islamic-extremism-grows-in-latinamerica-some-want-trump-to-take-action, accessed October 1, 2018.

25. Idem.

26. Christopher Sabatini, "Is there a credible Islamist threat in Latin America?", The Christian Science Monitor, January 29, 2017 https://www.csmonitor.com/World/Americas/Latin-AmericaMonitor/2017/0129/Is-there-a-credible-Islamist-threat-in-Latin-America, accessed October 2, 2018.

27. Michael Webster, "Hezbollah and Mexica Drug Cartels Operating in Mexico and U.S.", http:// banderasnews.com/0810/edat-mexhezbollah.htm, last accessed 11 April 2018.

28. "10 more criminal cases that highlight Islamic terror threat at US-Mexico border," https:// creepingsharia.wordpress.com/2017/01/30/10-cases-border-terror/, last accessed 7 April 2018.

29. See James Hill, "Building Security Cooperation in the Western Hemisphere," remarks at North-South Center, 3 March 2003, http://www.iwar.org.uk/news-achieve/2003/03-12/htm, accessed October 1, 2018; Jenny Falcon, "US Official: Al-Qaeda, Drug Traffickers May Establish Ties", Voice of America 2 (2004); and the fictional account of drug-drug-traffickers and "jihadists" working together in Steven Seagal and Tom Morrisey, The Way of the Shadow Wolves: The Deep State and the Hijacking of America, Phoenix, AZ, Fifth Palace Publishing, 2017. This last text received stated approval as a "hair's breadth from the truth" by then Senate candidate, Trump ally, and former Maricopa County Sheriff Joe Arpaio.

30. John Tofik Karam, "Crossing the Americas: The U.S. War on Terror and Arab Cross-Border Mobilizations in a South American Frontier Region", Comparative Studies of South Asia, Africa, and the Middle East 31-2 (2011), pp. 251-266.

31. Jerry Haar, "Radical Islam's Latin American connection," http://www.miamiherald.com/ opinion/op-ed/article46127140.html, last accessed 17 March 2018. 
32. Though, that does not stop some from compiling "case files" https:// creepingsharia.wordpress.com/2017/01/30/10-cases-border-terror/, last accessed 7 April 2018. 33. R. Evan Ellis, "Radical Islam in Latin America and the Caribbean: Implications for U.S. National Security," http://www.dtic.mil/dtic/tr/fulltext/u2/a618995.pdf, last accessed 19 March 2018.

34. C. Connell, Understanding Islam ..., p. VI.

35. R. E. Ellis, "Radical Islam in Latin America and the Caribbean ...", p. 9.

36. C. Connell, Understanding Islam ..., p. VI.

37. "Islam and the Global War on Terrorism in Latin America," http://www.pewforum.org/ 2006/04/06/islam-and-the-global-war-on-terrorism-in-latin-america/, last accessed 28 April 2018.

38. Jerusa Ali, "Bahamian and Brazilian Muslimahs: Struggle for Identity and Belonging," in Islam and the Americas, ed. Aisha Khan, Gainesville, University Press of Florida, 2015, p. 197.

39. Fitra Ismu Kusumo, Islam en América Latina. Tomo II: Migración Árabe a América Latina, Ciudad de México, Rumah Jade Production, 2013.

40. Edward Said, Orientalism, New York, Vintage Books, 1978.

41. See Eduardo Mendieta, "Ni Orientalismo ni Occidentalismo: Edward W. Said y el Latinoamericanismo", Tabula Rasa 5 (2006), pp. 67-83; Emmanuel Taub, Otredad, orientalidad e identidad: Nociones sobre la construcción de un otro oriental en la revista Caras y Caretas. 1898-1918, Buenos Aires, Teseo, 2008.

42. See Silvia Nagy-Zekmi, ed., Moros en la Costa: Orientalismo en Latinoamérica, Madrid: Iberoamericana, 2008; Rukhsana Qamber, "Anti-Islamic Bias in Sources on Latin America: Preliminary Findings", Islamic Studies 42 (2003), pp. 651-685 and "Inquisition Proceedings against Muslims in $16^{\text {th }}$ Century Latin America”, Islamic Studies 45 (2006), pp. 21-57; and Mikaela RogozenSoltar, "Managing Muslim Visibility: Conversion, Immigration, and Spanish Imaginaries of Islam", American Anthropologist 114 (2012), pp. 611-623.

43. For example Juan F. Caraballo-Resto's thesis at the University of Puerto Rico, "Palestinian Muslims as a 'Middle-Man Minority Group' in San Juan, Puerto Rico", San Juan, University of Puerto Rico, 2003.

44. Ian Bremmer, "The Top 5 Countries Where ISIS Gets Its Foreign Recruits," http://time.com/ 4739488/isis-iraq-syria-tunisia-saudi-arabia-russia/, last accessed 28 April 2018.

45. Richard Florida, "The Geography of Foreign ISIS Fighters," https://www.citylab.com/equity/ 2016/08/foreign-fighters-isis/493622/, last accessed 28 April 2018.

46. Frances Robles, "Trying to Stanch Trinidad's Flow of Young Recruits to ISIS," https:// www.nytimes.com/2017/02/21/world/americas/trying-to-stanch-trinidads-flow-of-youngrecruits-to-isis.html, last accessed 28 April 2018.

47. John McCoy and W. Andy Knight, "Homegrown Violent Extremism in Trinidad and Tobago: Local Patterns, Global Trends", Studies in Conflict and Terrorism 40-4 (2017), pp. 267-299.

48. Simon Cottee, "ISIS in the Caribbean," https://www.theatlantic.com/international/archive/ 2016/12/isis-trinidad/509930/, last accessed 28 April 2018.

49. "Official Statement of Dr. Bilal Philips on his Arrest in Phillippines," https:// muslimmatters.org/2014/09/13/official-statement-bilal-philips-arrest-philippines/, last accessed 28 April 2018.

50. Idem, $120 \mathrm{ff}$.

51. See Michael Weiss, ISIS: Inside the Army of Terror, New York, Regan Arts, 2016, p. 170.

52. While Wiktoriwicz wrote that Salafis are unified around a core creed that includes, "strict adherence to the concept of tawhid (the oneness of God) and ardent rejection of a role for human reason, logic, and desire," strict adherence to "the rules and guidance in the Qur'an and Sunna" and a yearning for eliminating "the biases of human subjectivity and self-interest" they have also divided into three major factions according to different contextual situations: purists, politicos, 
and jihadis. See Quintan Wiktoriwicz, "Anatomy of the Salafi Movement", Studies in Conflict and Terrorism 29 (2006), pp. 207-239.

53. During my fieldwork in June 2017 I spoke with two imams in Puerto Rico who were about to go to Trinidad to discuss the rise of Salafism in the Caribbean. I helped them prepare information and statistics on the various Muslim communities in the Caribbean including Puerto Rico, Cuba, Jamaica, Trinidad, and elsewhere. Our conversations and mutual research helped inform these estimates.

54. Mohamed-Ali Adraoui, "Salafism in France: Ideology, Practices and Contradictions", in Global Salafism: Islam's New Religious Movement, ed. Roel Meijer, Oxford, Oxford University Press, 2013, p. 366.

55. Terje Østebø, “Muslim Protests in Ethiopia," Lecture, University of Bergen, December 12, 2013.

56. "Caribbean to Caliphate," https://www.aljazeera.com/programmes/peopleandpower/ 2017/05/caribbean-caliphate-170517073332147.html, last accessed 28 April 2018.

57. Cf. Jeanne Baptiste, "More than Dawud and Jalut: Decriminalizing the Jamaat al Muslimeen and Madressa in Trinidad", in Islam in the Americas, ed. Aisha Khan, Gainesville, University Press of Florida, 2015, pp. 269-295.

58. Mahmood Mamdani, "Good Muslim, Bad Muslim: A Political Perspective on Culture and Terrorism”, American Anthropologist 104-3, 2002, pp. 766-775.

59. "Fear and Islam in Trinidad," https://dialogo-americas.com/en/articles/fear-and-islamtrinidad, last accessed 28 April 2018.

60. “Dābiq Magazine Issue \#5," http://jihadology.net/category/dabiq-magazine/, last accessed 28 April 2018.

61. S. Cottee, "ISIS in the Caribbean."

62. Sanjay Badri-Maharaj, "Globalization of the Jihadist Threat: Case Study of Trinidad and Tobago", Strategic Analysis 14-2 (2017), pp. 173-189.

63. Raoul A. Pantin, Days of Wrath: The 1990 Coup in Trinidad and Tobago, Lincoln, iUniverse, 2007, p. $\mathrm{X}$.

64. Prea Persaud, "Islam in Trinidad", in Encyclopedia of Latin American Religions, ed. Henri Gooren, Berlin, Springer, 2019.

65. R. Pantin, Days of Wrath ..., p. 145.

66. Chris Searle, "The Muslimeen Insurrection in Trinidad", Race \& Class 33-2 (1991), pp. 29-43.

67. See P. Persaud, "Islam in Trinidad".

68. C. Searle, "The Muslimeen Insurrection ...", p. 41.

69. R. Pantin, Days of Wrath ..., p. 154.

70. Danny Gold, "The Islamic Leader Who Tried to Overthrow Trinidad Has Mellowed...a Little,"https://news.vice.com/article/the-islamic-leader-who-tried-to-overthrow-trinidad-hasmellowed-a-little, last accessed 7 April 2018.

71. “I'm no ISIS Point Man: Yasim Abu Bakr," https://www.trinidadexpress.com/news/im-noisis--point-man-279688692.html, last accessed 7 April 2018.

72. S. Cottee, "ISIS in the Caribbean."

73. Roel Meijer, "Introduction”, in Global Salafism: Islam's New Religious Movement, ed. Roel Meijer, Oxford, Oxford University Press, 2013, p. 29.

74. Jeevan Deol and Zaheer Kazmi, eds., Contextualizing Jihadi Though, New York, Columbia University Press, 2011, p. 11.

75. Pedro Brieger and Enrique Herskowich, "The Muslim Community of Argentina", The Muslim World 91-1 (2002).

76. P. Brieger and E. Herskowich, "The Muslim Community ...”.

77. Judith Laikin Elkin, The Jews of Latin America, Boulder and London, Lynne Rienner Publishers, 2014. 
78. See earlier Breitbart report.

79. Harriett Alexander, "The Buenos Aires bomb, the Iranian allegations, and the accusations against Cristina Kirchner," https://www.telegraph.co.uk/news/worldnews/southamerica/ argentina/11356031/The-Buenos-Aires-bomb-the-Iranian-allegations-and-the-accusationsagainst-Cristina-Kirchner.html, last accessed 28 April 2018.

80. Frud Bezhan, "Explainer: Iran's Alleged Part In 1994 Bombing of Buenos Aires Jewish Center," https://www.rferl.org/a/iran-argentina-bombing-jewish/25004062.html, last accessed 28 April 2018.

81. Frances Martel, “'Islamic Fundamentalists Killed Nisman': Argentina Reacts to New 100-Page Prosecutor Investigation," http://www.breitbart.com/national-security/2015/03/06/islamicfundamentalists-killed-nisman-argentina-reacts-to-new-100-page-prosecutor-investigation/, last accessed 28 April 2018.

82. Mark Dubowitz and Toby Dershowitz, "Iranian Terror. Argentinian Cover Up. Justice at Last?”, https://www.nytimes.com/2017/12/11/opinion/argentina-kirchner-iran-nisman.html, last accessed 28 April 2018.

83. "Argentina co-sponsors memorial for attack on Israeli embassy," http:// www.israelnationalnews.com/News/News.aspx/243324, last accessed 28 April 2018.

84. Omri Elmaleh, "The Lebanese-Muslim Diaspora in the Triple Frontier (Argentina, Brazil and Paraguay)", in Encyclopedia of Latin American Religions, ed. Henri Gooren, Berlin, Springer, 2017.

85. Mike Fleming Jr. “'Triple Frontier' Finally Going: Affleck, Isaac, Pascal, Hunnam, Hedlund, Arjona In JC Chandor's Lineup," http://deadline.com/2018/03/triple-frontier-movie-ben-affleckoscar-isaac-pedro-pascal-charlie-hunnam-garrett-hedlund-adria-arjona-jc-chandor-

netflix-1202345230/, last accessed 28 April 2018.

86. “Triple Frontier," http://www.imdb.com/title/tt1488606/, last accessed 7 April, 2018.

87. John Tofik Karam, "Crossing the Americas: The U.S. War on Terror and Arab Cross-Border Mobilizations in a South American Frontier Region", Comparative Studies of South Asia, Africa and the Middle East 31-2 (2011), pp. 251-266.

88. See M. David Sills and Kevin Baggett in their esssay "Islam in Latin America" (Southern Baptist Journal of Theology 15-2 (2011), pp. 28-41) in which they claim that the Tres Fronteras region is Hezbollah's "Latin American headquarters" and that the two attacks in Argentina operated out of the Tres Fronteras region.

89. C. Connell, Understanding Islam ..., p. 32.

90. John Tofik Karam, "Anti-Semitism from the Standpoint of its Arab Victims in a South American Border Zone", Latin American and Caribbean Ethnic Studies 6-2 (2011), pp. 143-167.

91. Christina Civantos, Between Argentines and Arabs: Argentine Orientalism, Arab Immigrants, and the Writing of Identity, Albany, NY, State University of New York Press, 2006.

92. Kevin Funk, "A Political Economy of Arab-Latin American Relations: Notes and Theoretical Reflections from within the 'American Social Science' of IR", FLACSO-ISA Joint International Conference July 23-25, 2014 Buenos Aires, Argentina.

93. Frederick Jackson Turner, "The Significance of the Frontier in American History," a paper read at the meeting of the American Historical Association in Chicago, 12 July 1893, during the World Columbian Exposition.

94. Patricia Nelson Limerick, The Legacy of Conquest: The Unbroken Past of the American West, New York, Norton and Company, 1987.

95. See S. Huntington, The Clash of Civilizations.

96. C. Connell, Understanding Islam ..., p. 24.

97. C. Connell, Understanding Islam ..., p. 51.

98. C. Connell, Understanding Islam ..., p. 31.

99. Facebook Post, March 9, 8:44am. 
100. Erik Camayd-Freixas, Orientalism and Identity in Latin America Fashioning Self and Other from the (Post)Colonial Margin, Tucson, University of Arizona Press, 2013.

101.

\section{ABSTRACTS}

Surveying several conflicts, conversations, and the convergence of prejudices and fears in the Americas, this essay explores the linkages between Latin America and the Caribbean and the U.S. led global "War on Terror." Examining the parallels in politics, media, and rhetoric in places such as Trinidad and Tobago, Argentina, and the U.S., this essay examines how Muslims occupy a tenuous space in Latin American and Caribbean public spheres. Overall, it argues that the place of Islam and the lives of Muslim communities in the Americas are inherently intertwined with both local issues of societal concern, social justice, and class and the broader assumptions and farreaching frames of U.S. politics and that nation's leadership in the global "War on Terror."

Analisando vários conflitos, discussões e a convergência de preconceitos e medos nas Américas, este ensaio explora as relações entre a América Latina e as Caraíbas e os Estados Unidos, que levaram à "Guerra ao Terrorismo" global. Examinando o paralelismo na política, nos media e na retórica, em lugares como Trinidade e Tobago, Argentina e Caraíbas, este artigo analisa como os muçulmanos ocupam um lugar ténue na esfera pública da América Latina e das Caraíbas. No geral, argumenta que a prática do islão e as vidas das comunidades nas Américas estão intrinsecamente entrelaçadas, tanto com os problemas locais de preocupação societal, justiça social e classe, como com os pressupostos mais amplos e de longo alcance da política dos EUA e da liderança da nação na "Guerra ao Terrorismo" global.

\section{INDEX}

Keywords: islam, Americas, terrorism, border zones, islamophobia

Palavras-chave: Islão, Américas, terrorismo, zonas fronteiriças, islamofobia

\section{AUTHOR}

\section{KEN CHITWOOD}

University of Florida

kchitwood@ufl.edu 